말초신경병증에서 초음파검사의 응용

김지영

명지병원 신경과

\title{
Clinical Application of Ultrasonography in Peripheral Neuropathies
}

Jee Young Kim

Department of Neurology, Myongji Hospital, Goyang, Korea

Peripheral neuropathies are very diverse in etiology, pathogenesis, and clinical manifestations. The electrodiagnostic studies have been the most fundamental and important for diagnosis and classification of peripheral neuropathies. However, the electrodiagnostic studies cannot provide anatomical and structural information. Ultrasound can provide valuable information about pathologic changes of nerves and surrounding tissues and structural abnormalities. Due to the recent development of high resolution ultrasound, nerve ultrasound has been emerging as a promising tool for diagnosing and deciding on therapeutic strategies. This review focuses on the role of ultrasound in peripheral neuropathies.

J Neurosonol Neuroimag 201\$;10(1):13-1\$

Key Words: Ultrasound; Peripheral nervous system diseases; Peripheral nerves; Nerve compression syndromes; Polyneuropathies

Received: May 12, 2018

Revised: June 8, 2018

Accepted: June 8, 2018

Address for correspondence: Jee Young Kim

Department of Neurology, Myongji Hospital, 55 Hwasuro 14beon-gil, Deokyang-gu, Goyang 10475, Korea Tel: +82-31-810-6130 Fax: $+82-31-969-0500$ E-mail:nrkjy55@gmail.com

\section{서 론}

말초신경병증은 매우 다양한 원인으로 발생하며, 그 증상이 나 중증도도 환자마다 다르기 때문에 진단 및 치료가 어려운 신경계 질환이다. 말초신경병증을 진단하는데 있어 가장 기본 이 되고 중요한 검사는 아직까지도 전기진단학적 검사이지만, 초음파검사는 전기진단학적 검사가 제공할 수 없는 신경이나 주위 구조물의 해부학적 및 구조적 정보를 제공할 수 있어 그 유용성을 인정받고 있다. 1988년 Fornage와 Rifkin ${ }^{1}$ 에 의하 여 처음으로 말초신경의 정상 초음파 소견이 소개된 이후로 말 초신경병증에 대한 초음파검사의 임상적 적용 및 연구가 활발 히 이루어지고 있다. 초음파검사는 말초신경병증의 진단 및 예 후판단에 도움을 줄 뿐만 아니라 치료방법의 선택에 있어서도 그 유용성을 인정받아 임상에서 그 적용이 크게 증가하고 있 다. 본 논문은 말초신경병증에서 초음파검사를 어떻게 적용할 수 있는지 그 기본개념과 유용성을 간략하게 정리해보고자 한 다.

\section{본 론}

1. 초음파를 이용한 말초신경 평가

초음파를 이용하여 말초신경을 평가하려면 일반적으로 12 $\mathrm{MHz}$ 이상의 고주파 변환기(transducer)를 사용하여야 하며, 검사하는 신경의 횡단면과 종단면 영상을 모두 확인하여야 한 다. $^{2}$ 변환기를 위치시킬 때는 횡단면 영상일 경우에는 변환기 의 표식이 검사자의 왼쪽을 향하도록, 종단면 영상일 경우에는 표식을 환자의 머리를 향하여 위치시키도록 한다. ${ }^{2}$

\section{2. 정상 말초신경의 초음파 소견}

정상 말초신경을 초음파로 관찰하면 신경다발은 저에코로 신경외막이나 신경다발막은 고에코로 보여 종단면에서는 2 개 의 두꺼운 에코발생 선 사이에 여러 개의 평행한 에코발생 선 들이 주행하는 관모양의 구조로 보이고, 횡단면에서는 신경섬 유는 저에코 영역으로 신경다발막은 고에코 영역으로 번갈아 

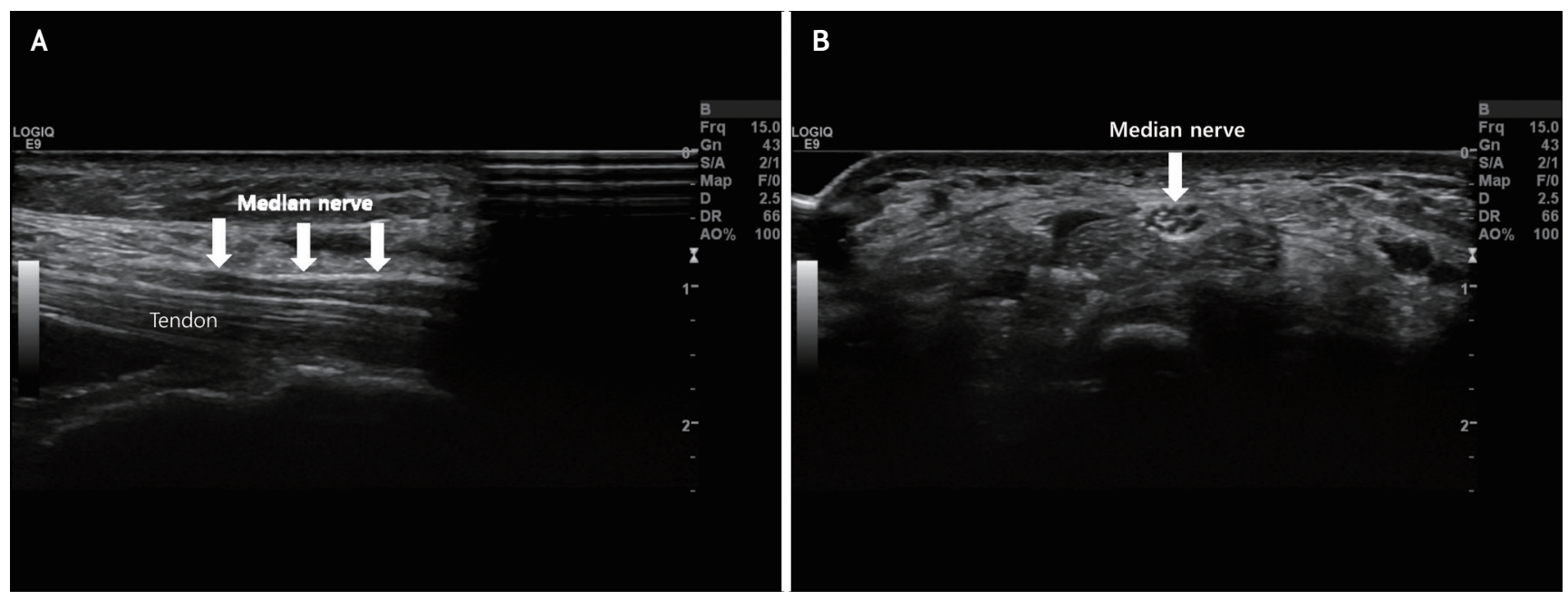

FIG. 1. Ultrasonographic findings of normal median nerve. (A) Longitudinal view of the median nerve (white arrows) at the wrist shows a tubular structure with two hyperechoic lines. (B) Transverse view of the median nerve (white arrow) at the wrist shows the typical "honeycomb" pattern.

분포하여 벌집형태로 보인다(Fig. 1). ${ }^{3}$

신경과 구분을 요하는 구조물은 혈관과 건(tendon)인데, 혈 관은 Doppler로 혈류의 방향에 따라 색깔로 표시되기 때문 에 비교적 구분이 용이하다. 건은 신경과 달리 많은 평행한 에 코발생 선들로 구성되어 섬유구조 형태로 보인다. ${ }^{4}$ 또한 변환 기와 조직의 각도에 따라 조직이 밝은 고에코 부위로 또는 어 두운 저에코 부위로 보일 수 있는데 이러한 조직의 이방향성 (anisotropy) 차이에 의해서도 신경과 건은 구분이 가능하다. ${ }^{5}$ 건은 신경에 비하여 높은 이방향성을 보이는 조직으로 초음파 에 노출되는 각도가 커지면 건은 고에코 영역으로 관찰된다. 또한 해당 팔이나 다리를 굽히거나 펴면 건은 신경보다 크게 움직이기 때문에 구분할 수 있다. ${ }^{5}$

\section{3. 신경초음파검사의 평가지표}

초음파를 통하여 말초신경의 이상을 검사할 때 평가하는 주 된 지표는 1) 횡단면적(cross-sectional area, CSA), 2) 혈관 분포, 3) 에코발생, 4) 운동성, 5) 주변의 구조물이다. 그중 가 장 중요한 지표는 $\mathrm{CSA}$ 이다. 일반적으로 면적은 신경의 에코발 생 가장자리 바로 안쪽으로 측정하며, 측정할 때마다 약간 차 이가 있을 수 있으므로 보통 3 번 정도 측정하여 평균값을 구하 는 것이 권유된다. $\mathrm{CSA}$ 를 측정할 때 한 가지 주의해야 할 점 은 변환기를 신경에 직각이 되도록 위치시킨 후 약간 누르면서 측정하는 것이 좋은데, 만일 직각이 되지 않을 경우 실제 영역 에 비하여 더 크게 측정될 수 있기 때문이다. ${ }^{3}$ 신경초음파검사 가 가장 많이 적용되는 포착신경병증(entrapment neuropathy)의 경우, 신경이 포착되는 부위에서는 상대적으로 신경이 얇아지는 반면에 포착 부위의 근위부 쪽에서는 비대되는 것을 관찰할 수 있다. 초음파에서 관찰되는 말초신경의 비대를 병적
인 것으로 판단할 때 다음의 두 방법을 흔히 사용하는데 1) 평 균 참고치의 2 표준편차 이상으로 커져있는 경우, 2) 같은 신 경에서 침범이 안된 영역보다 1.5 배 이상으로 증가된 경우이 다. ${ }^{6}$ 좀 더 객관적인 정량화를 위하여 최대 CSA와 최소 CSA 의 비율을 정량적으로 구하는 방법도 이용되는데, 한 연구에 서는 정중신경의 아래팔에서 측정한 $\mathrm{CSA}$ 와 손목에서 측정한 $\mathrm{CSA}$ 의 비율을 측정하는 것이 손목굴증후군(carpal tunnel syndrome, CTS) 진단의 민감도와 특이도를 향상시킬 수 있 다고 하였다. ${ }^{6}$ 또한 병측의 $\mathrm{CSA}$ 와 건측의 $\mathrm{CSA}$ 를 비교하여 병 변부위를 국소화하는데 도움을 얻거나 해당 신경병증이 국소 적으로 침범하는 질환인지 미만성으로 침범하는 질환인지 구 별하는데도 유용할 수 있다. ${ }^{4}$

말초신경의 혈관분포를 평가하는 것은 Doppler 기법을 이 용해야 가능하다. 말초신경의 혈류공급은 신경 바깥과 신경내 혈관의 풍부한 문합시스템에 의하여 이루어지는데 포착성 또 는 염증성 신경병증에서는 신경바깥이나 신경내의 혈류가 증 가하는 것을 발견할 수 있다. ${ }^{5}$ 과거 한 연구에서 CTS에서 과 다한 혈관분포와 CTS의 중증도 간의 유의한 연관성을 보고하 였는데, ${ }^{7}$ 혈관분포는 체온이나 교감신경계의 긴장도 등의 요인 에 의하여 영향을 받을 수 있어 임상적 적용에는 제한이 있다.

말초신경의 에코발생은 앞서 설명한 바와 같이 정상 말초신 경의 경우 종단면에서는 관의 구조로 횡단면에서는 벌집구조 로 관찰된다. 말초신경병증에서는 이러한 정상적인 에코구조 (echostructure)가 소실되는 것을 관찰할 수 있으나, 이는 검 사자의 숙련도에 영향을 많이 받기 때문에 객관적인 지표로 이 용되기가 어렵다.

말초신경의 운동성은 보통 포착신경병증에서 평가하는데 방 법은 CTS가 의심되는 경우에는 환자에게 손가락을 굽히게 하 고 팔꿉굴증후군(cubital tunnel syndrome)이 의심되는 경우 
에는 팔꿈치를 굽히게 하여 신경의 움직임을 확인한다. ${ }^{4}$ 일반 적으로 포착신경병증에서는 신경이 원래 위치에서 미끄러지는 정도(slippage)가 감소하는 것을 관찰할 수 있으나, 이 또한 검사자의 숙련도에 많은 영향을 받기 때문에 객관적인 지표로 이용되기는 어려울 수 있다.

이와 더불어 확인해야 할 것은 말초신경 주변의 구조물이 다. 포착신경병증이 의심될 때, 신경이 정상적인 해부학적 구 조에 의하여 포착되는 것인지 아니면 혈관기형이나 골절, 종양 이나 낭종 등에 의하여 압박되는 것은 아닌지 확인하여야 한다 (Figs. 2, 3). ${ }^{5}$ 외상의 병력이 있다면 외상 후의 혈종이나 굳은 살(callus)에 의하여 말초신경이 압박되는 경우도 고려해야 하 며, 수술 후 그 부위에 신경병증이 의심된다면 수술로 생긴 흥

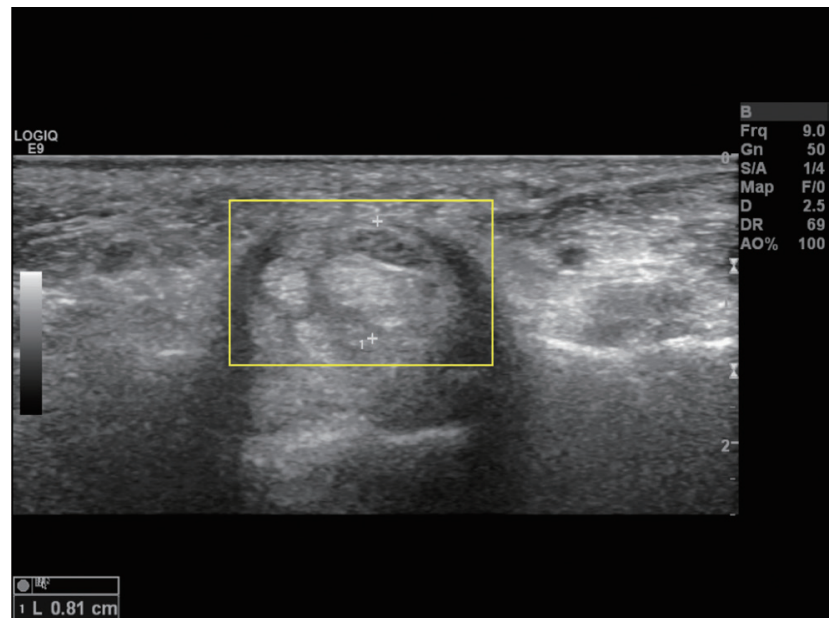

FIG. 2. Amyloid arthropathy with the carpal tunnel syndrome. The image shows heterogeneous echogenicity materials with effusion in the mid carpal joint with ventral convexity of the transverse carpal ligament.

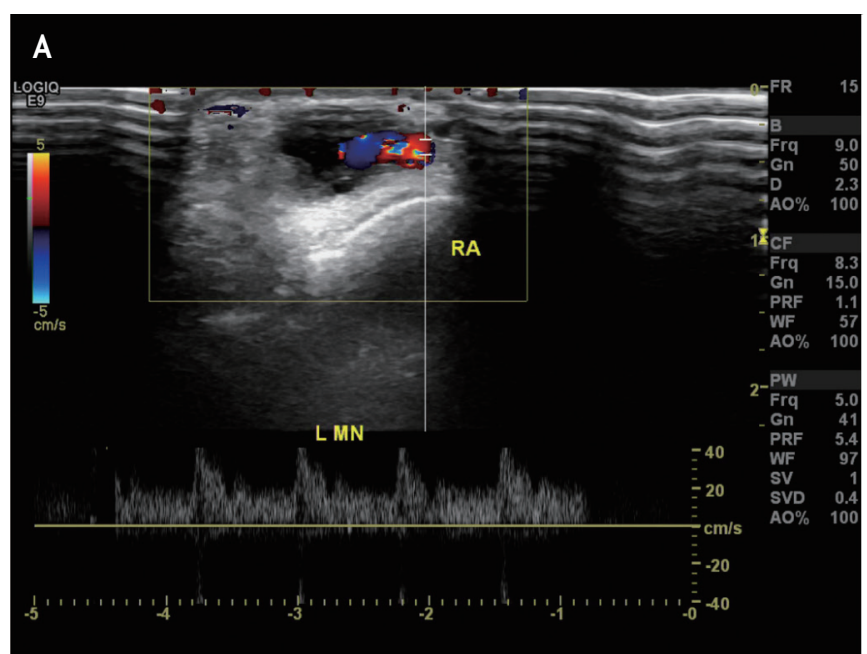

터에 의하여 신경이 압박될 수도 있으므로 이러한 주변 구조물 의 이상이 없는지 확인해야 한다. 장기간의 반복적인 미세외상 에 의하여 발생한다고 알려진 Morton's neuroma의 경우 주 로 세 번째 중족골의 앞쪽에 호발하므로 발의 통증을 호소하는 환자에서는 이에 대한 평가가 필요할 수 있다(Fig. 4). ${ }^{8}$

\section{4. 국소신경병증의 초음파 소견}

국소신경병증은 개별 말초신경에 병변을 유발하는 질환으로 외적인 또는 내적인 요인으로 일어난다. 외적인 요인으로는 손 목에서 발생하는 CTS 또는 팔꿈치에서의 팔꿉굴증후군과 같 이 말초신경에 압박이나 손상을 유발할 수 있는 해부학적 구조 에 의한 것이며, 그 외 외상으로 인하여 신경의 일부가 손상되 어 발생할 수 있다. ${ }^{9}$ 내적인 요인으로는 신경종, 신경막종양,

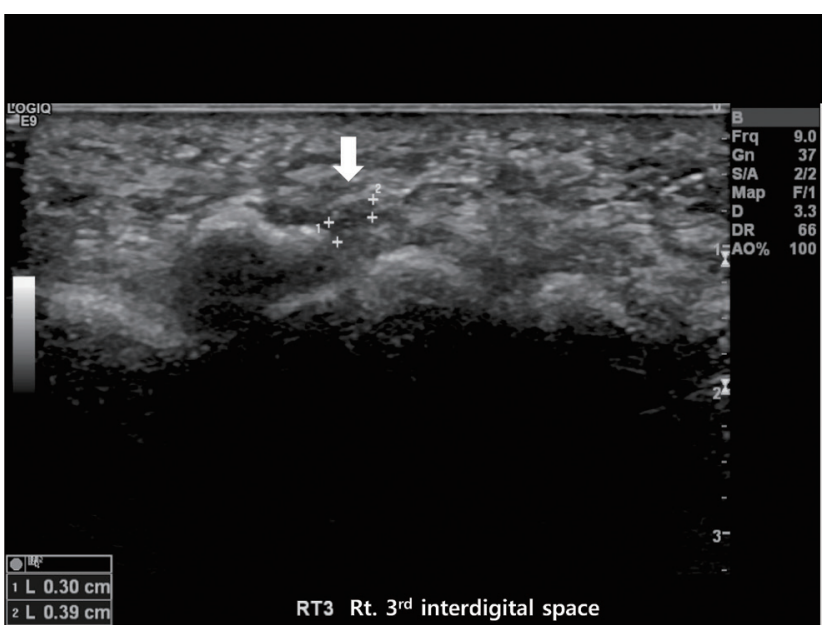

FIG. 4. Morton's neuroma. A hypoechoic solid nodule (white arrow, $0.3 \times 0.35 \mathrm{~cm}$ ) is observed in the third interdigital space of right foot.

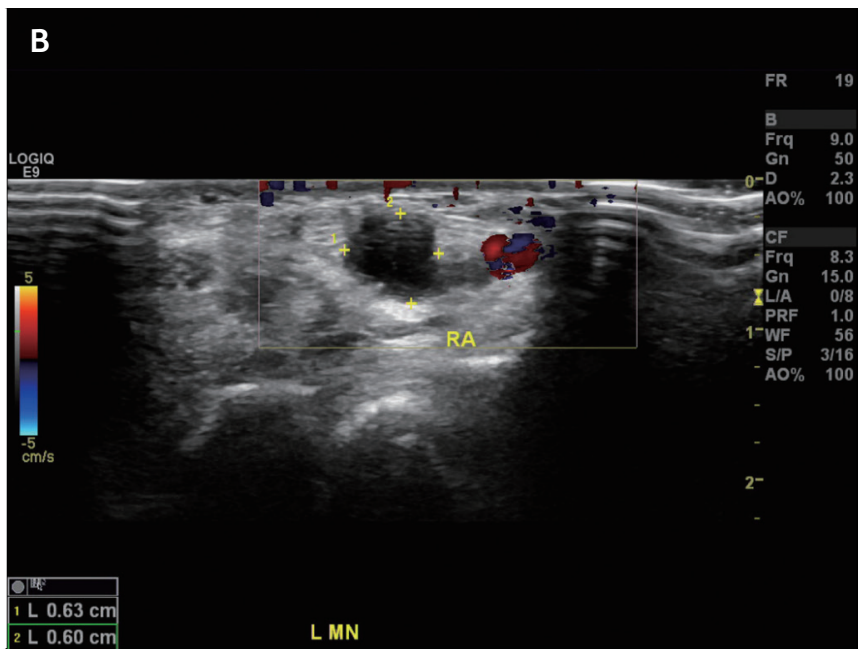

FIG. 3. Ultrasonographic findings of ganglionic cysts found in left hand of a patient with left carpal tunnel syndrome. (A) One cystic mass (about $1.0 \times 0.8 \mathrm{~cm}$ ) is observed above the left median nerve. The radial artery is passing adjacent to the cystic mass. (B) The other cystic mass (about $0.63 \times 0.5$ $\mathrm{cm}$ ) is located at more distal area and extended to the radiocarpal joint. 
신경경색 등인데 외적인 요인보다는 흔하지 않다. ${ }^{9}$ 국소신경병 증을 진단하는데 있어 전기진단학적 검사가 가장 기본적이지 만 이 검사만으로는 말초신경에 압박 또는 손상을 줄 수 있는 신경 주변의 구조적인 문제를 확인할 수 없으며, 그 원인을 정 확하게 유추하기 어려울 때도 있고 때때로 위음성이나 위양성 의 결과를 얻을 수가 있다. 또한 병변을 국소화하는데 있어 침 근전도검사가 유용할 때가 많으나 검사과정에서 환자에게 통 증을 유발하기 때문에 충분한 검사를 하는데 제약이 따른다. 이러한 전기진단학적 검사의 한계점을 보완하는데 신경초음파 가 유용하게 이용될 수 있으며, 병행할 경우 진단의 민감도와 특이도를 향상시킬 수 있다.

가장 널리 이용되고 가장 많이 연구가 진행된 국소신경병증 은 손목에서의 정중신경병증인 CTS로 종단면에서 변환기를 손목과 평행이 되게 하여 손목을 가로지르면서 검사한다. 손목 부위의 횡단면 영상에서 $\mathrm{CSA}$ 의 증가, 혈관분포와 에코발생의 감소, 정중신경의 운동성 감소 등이 CTS의 가장 대표적인 소 견이다(Fig. $5 \mathrm{~A}){ }^{4}$ 그 외에 flexor retinaculum의 휘어짐이나 종단면에서 flexor retinaculum 아래로 정중신경이 포착되는 것을 확인할 수 있다(Fig. 5B). ${ }^{4}$ 드물지만 다른 해부학적 변 이를 확인할 수 있는데, CTS의 약 $20 \%$ 환자에서 발견이 되는 bifid median nerve 등은 시각적 정보를 제공하지 않는 전기 진단학적 검사로는 확인이 어렵다. ${ }^{9}$

두 번째로 흔한 포착신경병증은 팔꿈치에서의 척골신경병증 이다. Medial epicondyle과 olecranon 사이의 홈에서 횡단면 으로 척골신경을 관찰한 후 medial epicodyle의 원위부 $5 \mathrm{~cm}$ 하방에 변환기를 위치시킨 다음 상방으로 이동시켜 medial epicondyle의 근위부 $5 \mathrm{~cm}$ 부위까지 관찰한다. ${ }^{9}$ 이 때 가장 척골신경이 팽대된 곳을 확인하여 $\mathrm{CSA}$ 를 측정한다. 또한, 팔
꿈치를 구부릴 때 척골신경의 불완전탈구(subluxation)나 이 탈(dislocation)이 없는지 확인하는데 척골신경이 정상 위치 에서 벗어난 상태에서 신경전도검사를 시행하면 위음성의 결 과를 보일 수 있어 주의를 요한다. 따라서 팔꿈치에서의 척골 신경병증이 의심되는 환자에서는 신경초음파를 통하여 신경의 팽대뿐만 아니라 이탈이나 불완전탈구의 여부를 확인하도록 한다.

\section{5. 다발신경병증의 신경초음파 소견}

다발신경병증에서의 신경초음파검사에 대한 체계적인 기 준은 아직 마련되어 있지 않고 일부 질환에 대해서만 제한적 으로 사용되고 있다. 급성 염증성 탈수초다발신경병증(acute inflammatory demyelinating polyneuropathy, AIDP) 또 는 만성 염증성 탈수초다발신경병증(chronic inflammatory demyelinating polyneuropathy, CIDP), 다초점운동신 경병증(multifocal motor neuropathy) 또는 유전성 질환인 charcot-marie-tooth (CMT) 신경병증을 대상으로 신경초 음파검사를 임상으로 적용하거나 그 유용성에 대한 연구가 진 행되고 있다.

\section{6. 면역매개성 신경병증}

대표적인 자가면역성 신경병증의 하나인 CIDP는 운동 및 감각기능의 소실이 호전과 악화를 반복하며 진행을 하는 질 환이다. $\mathrm{CIDP}$ 의 진단은 임상경과와 전기진단학적 검사 결과 에 의존하는데 환자들마다 임상증상이 다르고 한 환자에서 도 경과에 따라 다양한 증상을 보이기 때문에 진단이 쉽지 않
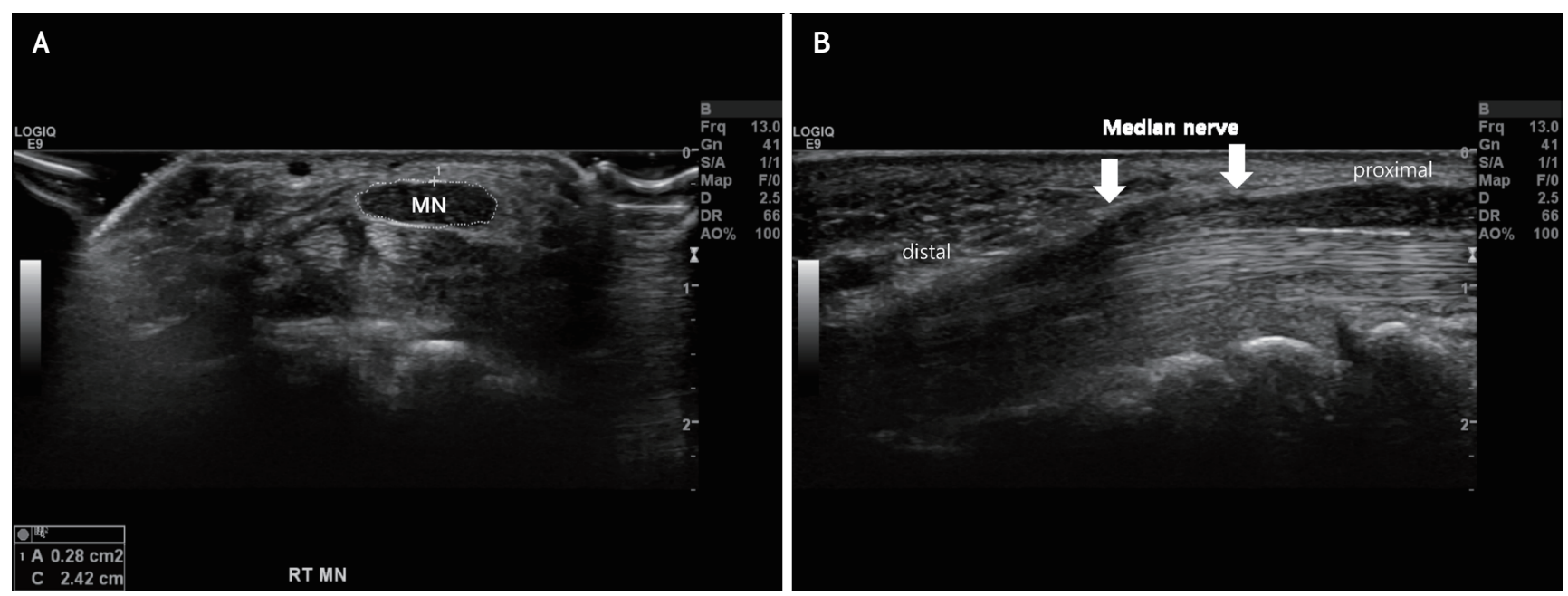

FIG. 5. Ultrasonographic findings of the carpal tunnel syndrome. (A) Transverse view of the median nerve at the right wrist shows a significant nerve swelling at just proximal to the carpal tunnel. The median nerve became enlarged and hypoechoic with loss of normal echogenicity. The cross sectional area is measured about $0.28 \mathrm{~cm}^{2}$. (B) Longitudinal view demonstrates flattening of the median nerve (white arrows) in the carpal tunnel. 
다. CIDP에 대한 신경초음파 연구는 오래되지 않았는데 초기 몇몇 연구에서 상완신경총의 비대와 사지의 일부 말초신경에 서도 비대가 관찰된다고 보고하였다. ${ }^{10}$ 이러한 신경의 팽대가 $\mathrm{CIDP}$ 에서 탈수초화 및 재수초화 과정이 반복되면서 나타나는 병리학적 특징인 “양파구근(onion-bulb)" 형성과 연관된 것 으로 보인다. ${ }^{11}$ 2009년에 CIDP 환자들을 대상으로 정중신경 과 척골신경의 $\mathrm{CSA}$ 를 측정하여 발표한 연구에서 저자들은 미 만성의 신경비대가 $\mathrm{CIDP}$ 에서 관찰될 수 있는 초음파 소견이 며, 대상 환자들의 신경전도속도와 CSA가 서로 역관계에 있음 을 주장하였다. ${ }^{12}$ 따라서 $\mathrm{CIDP}$ 가 의심되는 환자에서 초음파를 이용하여 근위부뿐만 아니라 원위부 말초신경의 전반적인 신 경팽대 및 $\mathrm{CSA}$ 의 증가를 관찰한다면 조기 진단이 용이해질 것 이다. 때때로 환자의 경과와 전기진단학적 검사 결과만으로 아 급성 발현의 $\mathrm{CIDP}$ 와 점차 진행하는 $\mathrm{AIDP}$ 를 감별하기가 어려 울 때가 있는데, 2014년에 발표된 한 연구에서, 이러한 경우에 초음파검사가 얼마나 진단율을 높일 수 있는지 확인하였다. 저 자들은 네 부위에서 측정한 척골, 요골, 장딴지 신경의 $\mathrm{CSA}$ 를 이용하여 ultrasound score를 개발하여 비교하였는데, 이 점 수를 통하여 민감도 $80 \%$ 와 특이도 $100 \%$ 로 AIDP가 아닌 아급 성 $\mathrm{CIDP}$ 로 진단할 수 있다고 하였다. ${ }^{13}$ 이러한 초음파검사를 통하여 신뢰할 만한 정량적 지표가 개발된다면 다소 까다로운 전기진단학적 기준에만 의존하지 않고 조기에 진단하여 치료 를 할 수 있을 것으로 기대된다.

AIDP 또는 Guillain-Barré syndrome (GBS)은 급성 발 현으로 위로 진행하는 사지마비, 심부건반사 저하 등을 보이 는 면역매개성 신경병증으로 단기간 내에 호흡부전이 올 수 있 으므로 빠른 진단과 조기 치료가 중요한 질환이다. 진단은 주 로 임상증상과 신경학 진찰 소견에만 의존하여 내리게 되는 데, 발현 후 수일 내에는 뇌척수액검사에서의 알부민세포해리 (albuminocytologic dissociation)나 전기진단학적 변화가 뚜 렷하지 않기 때문이다. 이렇게 진단이 쉽지 않은 초기에 신경 초음파에서 특징적인 소견이 확인된다면 조기 진단에 큰 도움 이 될 수 있을 것이다. AIDP 환자 17명을 대상으로 한 초기 연 구에서 발현 4주 이내의 환자들에서 정중신경과 척골신경의 $\mathrm{CSA}$ 가 건강대조군에 비하여 증가된다는 것을 보여 주었는데, 이는 초기 염증성 변화에 의한 신경의 부종과 신경내압의 증 가로 인한 것으로 추측된다. ${ }^{22}$ 이후로 발표된 연구들에서 발현 후 수일 된 GBS 환자들에서 급성기에 미주신경을 포함한 말초 신경과 신경뿌리 및 경추신경 등에서 신경비대가 관찰되었는 데, 말초신경전도검사가 정상인 급성기에 또는 비전형적인 경 과를 보이는 증례에서 이러한 신경초음파 소견이 발견된다면 조기진단을 하는데 도움이 될 것이다. ${ }^{14,15}$ 2016년에 증상 발현 후 2-3일 이내인 GBS 환자들을 대상으로 면역글로불린 주사 치료 후 10-14일에 그리고 발현 후 6개월이 지난 시점에 신경 초음파검사와 말초신경전도검사를 연속적으로 시행하여 대조 군과 비교를 한 연구가 있었는데, 환자군의 발현기에 대조군에
비하여 장딴지신경을 제외한 모든 말초신경, 미주신경 및 경추 신경들이 유의하게 비대되는 것을 보여주었다. ${ }^{16}$ 또 저자들은 6 개월이 지난 시점에서는 경추신경과 미주신경의 크기가 정상 으로 회복되는 것을 기술하여 경추신경에서 관찰되는 초음파 소견의 변화가 질환의 경과를 반영할 수 있다고 시사하였다. ${ }^{16}$ 흥미로운 것은 자율신경장애가 있는 환자들에서 미주신경이 현저히 비대되어 초기 GBS 환자들에서 미주신경의 비대가 관 찰된다면 자율신경장애가 동반될 위험이 있다는 것을 예측하 여 볼 수 있을 것이다. ${ }^{16}$

\section{7. 유전성 신경병증}

CMT는 대표적인 유전성 신경병증으로 인구 2,500 명 당 1 명 꼴로 발병하는 유전성 질환으로서는 비교적 드물지 않은 질환 이다. 다양한 세부 아형들과 수많은 유전자 이상이 알려져 있 고 유전자 검사가 상용화되긴 하였으나 전기진단학적 검사로 탈수초형과 축삭형으로 분류하는 것은 현재까지도 가장 중요 하다. 그러나 탈수초형과 축삭형의 중간형을 보이는 많은 세부 아형들이나 중증으로 진행되어 전기진단학적으로 감별이 어려 운 경우에는 전기진단학적 검사만으로 분류하는데 제한이 있 어 최근 들어 신경초음파검사를 병행하여 좀 더 명확하게 진 단하고자 하는 노력들이 이루어지고 있다. 신경초음파 연구 는 $\mathrm{CMT}$ 의 여러 아형들 중에서 탈수초형인 CMT1에 대하여 주 로 연구가 진행되었다. Cartwright 등기 이 처음으로 Charcot-Marie-Tooth disease type 1B (CMT1B)에서의 신경초 음파 연구를 발표하였는데, $\mathrm{CMT1B}$ 가족과 건강대조군에서 말 초신경의 $\mathrm{CSA}$ 를 측정하여 비교하였다. 이 연구 결과 대조군 에 비하여 환자군에서 CSA가 현저하게 증가됨을 보여주었다. 이후 CMT1과 CIDP 환자들을 비교한 연구들이 발표되었는데, $\mathrm{CIDP}$ 군에 비해서 $\mathrm{CMT} 1$ 환자군에서 말초신경의 전반적인 부 종 및 비대 소견을 보여주었다. ${ }^{18,19}$ 이러한 결과들은 CMT1이 의심되는 환자에서 이러한 소견이 선별검사에 이용될 수 있음 을 시사한다. 그러나 다른 아형들에서는 아직 연구가 많이 진 행되지 않아 향후 여러 아형들에서 나타나는 신경초음파의 소 견 및 유전성 신경병증에서의 신경초음파의 임상적 유용성에 대한 추가적인 연구들이 필요하다.

\section{결 론}

말초신경병증이 의심되는 환자를 진료할 때 아직까지도 전 기진단학적 검사가 가장 중요하고 기본적인 진단도구이지만 신경초음파 검사의 발전으로 전기진단학적 검사에서 얻을 수 없는 해부학적 및 구조적인 정보를 얻을 수 있게 되었다. 포착 신경병증에서는 초음파검사를 통하여 1) 포착된 부위의 국소 화, 2) 해부학적 변이, 3) 내인성 또는 외인성 요인 등을 확인 
할 수 있다는 큰 장점이 있다. 또한 포착신경병증의 경우 초음 파 유도하의 중재적 치료를 할 수 있어 안전하고 유용한 치료 수단을 제공한다. 다발신경병증에서는 아직 정립된 근거가 부 족하기는 하지만 1) 전기진단학적 검사와 병행하여 조기 진단 에 활용, 2) 다발신경병증에 동반된 다른 병변이나 포착신경병 증을 확인하는데 응용될 수 있다. 또한 향후 각 질환별 특징적 인 초음파 소견이 확인되면 각 질환의 병태생리를 이해하는데 도움이 될 수 있을 것이다. $\mathrm{CIDP}, \mathrm{AIDP}$ 등의 면역매개성 신 경병증에서 신경초음파의 이상 소견과 전기진단학적 검사 결 과에 대한 연관성을 찾고자 하는 연구들이 있어 왔으나 아직까 지는 그 결과에 대해서는 논란의 여지가 많은 상태로 향후 면 역매개성 신경병증에서 신경초음파 소견과 전기진단학적 결과 또는 환자들의 기능적 결과 간의 연관성을 찾고자 하는 연구가 필요할 것이다.

\section{REFERENCES}

1. Fornage BD, Rifkin MD. Ultrasound examination of the hand and foot. Radiol Clin North Am. 1988;26:109-129.

2. Cartwright MS, Walker FO. Neuromuscular ultrasound in common entrapment neuropathies. Muscle Nerve. 2013;48:696-704.

3. Silvestri E, Martinoli C, Derchi LE, Bertolotto M, Chiaramondia M, Rosenberg I. Echotexture of peripheral nerves: correlation between US and histologic findings and criteria to differentiate tendons. Radiology. 1995;197:291-296.

4. Kerasnoudis A, Tsivgoulis G. Nerve ultrasound in peripheral neuropathies: a review. J Neuroimaging. 2015;25:528-538.

5. Visser LH, Beekman R. Ultrasound of peripheral nerves. In: Walker FO, Cartwright MS. Neuromuscular ultrasound. 1st ed. Philadelphia: Elsevier Saunders. 2011;24-36.

6. Hobson-Webb LD, Massey JM, Juel VC, Sanders DB. The ultrasonographic wrist-to-forearm median nerve area ratio in carpal tunnel syndrome. Clin Neurophysiol. 2008;119:13531357.

7. Ghasemi-Esfe AR, Khalilzadeh O, Vaziri-Bozorg SM, Jajroudi M, Shakiba M, Mazloumi M, et al. Color and power Doppler US for diagnosing carpal tunnel syndrome and determining its severity: a quantitative image processing method. Radiology. 2011;261:499-506.

8. 8. Jain S, Mannan K. The diagnosis and management of Morton's neuroma: a literature review. Foot Ankle Spec. 2013;6:307-317.
9. Cartwright MS. Ultrasound of focal neuropathies. In: Walker FO, Cartwright MS. Neuromuscular ultrasound. 1st ed. Philadelphia: Elsevier Saunders. 2011;72-90.

10. Taniguchi N, Itoh K, Wang Y, Omoto K, Shigeta K, Fujii Y, et al. Sonographic detection of diffuse peripheral nerve hypertrophy in chronic inflammatory demyelinating polyradiculoneuropathy. J Clin Ultrasound. 2000;28:488-491.

11. Matsuda M, Ikeda S, Sakurai S, Nezu A, Yanagisawa N, Inuzuka T. Hypertrophic neuritis due to chronic inflammatory demyelinating polyradiculoneuropathy (CIDP): a postmortem pathological study. Muscle Nerve. 1996;19:163-169.

12. Zaidman CM, AL-Lozi M, Pestronk A. Peripheral nerve size in normals and patients with polyneuropathy: an ultrasound study. Muscle Nerve. 2009;40:960-966.

13. Kerasnoudis A, Pitarokoili K, Behrendt V, Gold R, Yoon MS. Bochum ultrasound score versus clinical and electrophysiological parameters in distinguishing acute-onset chronic from acute inflammatory demyelinating polyneuropathy. Muscle Nerve. 2015;51:846-852.

14. Grimm A, Décard BF, Axer H. Ultrasonography of the peripheral nervous system in the early stage of Guillain-Barré syndrome. J Peripher Nerv Syst. 2014;19:234-241.

15. Gallardo E, Sedano MJ, Orizaola P, Sánchez-Juan P, González-Suárez A, García A, et al. Spinal nerve involvement in early Guillain-Barré syndrome: a clinico-electrophysiological, ultrasonographic and pathological study. Clin Neurophysiol. 2015;126:810-819.

16. Grimm A, Décard BF, Schramm A, Pröbstel AK, Rasenack M, Axer $\mathrm{H}$, et al. Ultrasound and electrophysiologic findings in patients with Guillain-Barré syndrome at disease onset and over a period of six months. Clin Neurophysiol. 2016;127:16571663.

17. Cartwright MS, Brown ME, Eulitt P, Walker FO, Lawson VH, Caress JB. Diagnostic nerve ultrasound in Charcot-Marie-Tooth disease type $1 \mathrm{~B}$. Muscle Nerve. 2009;40:98-102.

18. Sugimoto T, Ochi K, Hosomi N, Takahashi T, Ueno H, Nakamura $\mathrm{T}$, et al. Ultrasonographic nerve enlargement of the median and ulnar nerves and the cervical nerve roots in patients with demyelinating Charcot-Marie-Tooth disease: distinction from patients with chronic inflammatory demyelinating polyneuropathy. J Neurol. 2013;260:2580-2587.

19. Zaidman CM, Harms MB, Pestronk A. Ultrasound of inherited vs. acquired demyelinating polyneuropathies. J Neurol. 2013;260:3115-3121. 